Historia y comunicación social

ISSN: $1137-0734$

http://dx.doi.org/10.5209/hics.75717

\title{
Sapag, Pablo (2020) Syria in perspective. From externally aggravated crisis to national reconstruction.
} Madrid: Ediciones Complutense.

The armed conflict that erupted in Syria in 2011 attracted the attention of the international media almost from the first violent clashes. In the context of the Arab Spring, domestic Syrian divisions were exploited to such an extent that within weeks the conflict had become internationalised. Syria became the arena for the geopolitical rivalries of our age.

However, the information provided by the media was sometimes inconsistent, biased or oversimplified. The last hour swallowed up the meaning of the conflict as a much deeper crisis, dismissing it as an episode in the post-Cold War breakdown of the international status quo.

In turn, this convoluted chess game drove to a distorted picture of the Syrian daily life. To this complex clash of interests, in order to understand the events in Syria, it is also necessary to add the serious crisis of Western journalism. On the one hand, much of the information was produced by journalists who earned a few hundred euros a week, covering crises of different kinds throughout the world. On the other hand, media anxiety forced journalists to deal with a flood of data that, in many cases, was impossible to verify.

Pablo Sapag's book manages to avoid the rushed analyses, rumours, exaggerated figures and hidden data that dominated the international coverage of the armed conflict in Syria. Syria in Perspective holds an important place in the bibliography in Spanish and English on this conflict, since it offers a measured and thoughtful analysis of the crisis that goes beyond the violent clash that broke in 2011.

The propagandistic account of the conflicting sides is a common thread throughout the book, providing key information to understand the political, social and economic structure of the country. The author presents, from an informed and experienced point of view, the historical social and religious tensions, as well as the model of coexistence that shapes the country's specificity. Adopting a multidimensional approach to the conflict, Sapag includes a look at the external interests that explain, to a large extent, the internationalisation of the conflict. The book also draws on an extensive bibliography of sources in English, Arabic, French and Spanish, including access to figures such as the Syrian president, Bashar al-Asad, and the Minister of State for National Reconciliation Affairs, Ali Haidar.

With an additional chapter in the English version, as compared to the Spanish editions $(2017,2019)$, the book is divided into eight chapters. After a brief introduction, the author begins by reviewing the origins of the multi-confessional Syrian state and its socio-political context, as well as the country's historical relationship with the Ottoman Empire and France. In the third chapter, the author analyses internal and external factors that taken in isolation do not explain the causes of the war, although combined led to an extension of the violence. Thus, factors that were ignored in Western media analyses are addressed, including climatic aspects, such as drought; economic issues, such as the withdrawal of agricultural subsidies; and political changes, such as the shift in traditional alliances between political parties and certain social sectors. Next, Sapag reviews Syria's relations with regional states, like Saudi Arabia, Qatar, Iran and Turkey, and with other states on the international stage that are relevant to the conflict, Russia and the US among others.

This chapter discusses how they have conditioned the intensity with which the war broke out and how it has developed, as well as the dependence of some of the local actors on foreign involvement. This chapter discusses how they have conditioned the intensity of the war and its evolution, as well as the dependency of some of the local actors on foreign assistance.

The following chapters are of particular interest due to the author's background and detailed knowledge of the region. Of special note is the chapter on the Syrian media and the analysis of the role that propaganda has played in the crisis. Pablo Sapag emphasises how both new and traditional media have resorted to propaganda techniques in an attempt to control the flow of information about events on Syrian territory. The author explains in depth the manipulation techniques and the effects they produced. It is not by chance that Pablo Sapag is a professor of communication and has worked as a journalist in the International Department of Telemadrid.

Alongside this, another of the most attractive chapters of the book, given the confusion and lack of knowledge that was evident in the coverage of the conflict, is the one devoted to local actors. The instrumentalisation of the Syrian crisis as a re-enactment of international geopolitical disputes downplayed local tensions and blurred the particularities of the local actors involved in the conflict. This was further exacerbated by the way some of 
them acted as proxies of major powers, which distorted their specificities, their behaviour and their distinctive political agenda. Syria in perspective's author, while keeping in mind the connections between the local and international actors themselves, distinguishes each actor's singularities, from the katibas under the umbrella of the Free Syrian Army, the National Defence to Jabhat al-Nusra or the Islamic State, to name a few examples.

In this English edition, the section on peace talks has been expanded into a chapter with updated and more detailed information on the most recent state of the negotiations. Finally, the book closes with a new chapter on the current situation in Syria, where the author analyses the impact of the COVID-19 pandemic on the country and, specifically, on the resolution of the crisis, and addresses the consequences of the most recent economic sanctions that the United States and the European Union have imposed on Syria.

In conclusion, Syria in Perspective is an outstanding contribution to the literature on the Syrian armed conflict and media coverage of armed conflicts after the end of the Cold War. The media content that frames the book makes it particularly appealing to journalists. However, its straightforward writing makes it an easyto-read book, recommended for any citizen who wants to know the details of the Syrian crisis, beyond the stereotypes and standardised narratives of the mainstream media.

Laura Pérez Rastrilla

Universidad Europea de Madrid

laura.rastrilla@gmail.com 